\title{
ONOMÁVEIN
}

Journal of linguistics, philology and translation

\section{Linking Content and Language-Integrated \\ Learning (CLIL) and Task-based Language \\ Teaching (TBLT) in an effective way: \\ a methodological proposal}

\author{
António Lopes \\ Universidade do Algarve
}

Special

Issue

$-\mathbf{V I}-$

Language

Teaching

Research from a Global

Perspective

2020
ONOMÁZEIN | Special Issue VI - Language Teaching Research from a Global Perspective: 05-22 DOI: 10.7764/onomazein.ne6.01 ISSN: 0718-5758

\section{(c) $(\mathrm{i})$}

António Lopes : Departamento de Didácticas Específicas, Universidade do Algarve. | E-mail: alopes@ualg.pt

Received: July 13, 2018

Accepted: January 15, 2019 


\section{Abstract}

CLIL and TBLT are approaches that have increasingly captured the attention of both teachers and researchers, and many of the latter have already discussed the ways in which they can be brought together. One of the challenges encountered in the implementation of CLIL has been the discrepancy between the level required to carry out the work for content learning and the students' actual level. One of the solutions may lie in resorting to TBLT, where language is regarded as action and the learner seen as a social actor engaged in real-life-like activities. However, in CLIL, the task being proposed to the students has to be appropriate to their level and their ability to internalise conceptual knowledge. In order to bridge some of the methodological gaps between CLIL and TBLT, a framework for designing content-oriented tasks, based on the one advanced for the project PETALL, has been developed to help teachers plan their CLIL activities. After a theoretical introduction to the principles of Taskbased Learning and its integration with CLIL, a template designed to systematise the task is provided and discussed.

Keywords: Content and Language-Integrated Learning; Task-based Language Teaching; Language Teaching. 


\section{Introduction}

Two of the approaches that have systematically been at forefront of language teaching research and that have consistently drawn the attention of both practitioners and policy-makers are Content and Language-Integrated Learning (CLIL) and Task-based Language Teaching (TBLT). Both CLIL and TBLT emerged in the 1980s (Ahmadian, 2016; Bygate, 2016; Hanesová, 2015) in the light of the principles of Communicative Language Teaching (CLT). Far from having become outdated, their theoretical tenets and methodological solutions have proven to be of great value in terms of finding ways to meet the current needs of contemporary society, in particular as far as the latest technological developments and skill requirements are concerned. The fact that their roots lie in CLT makes it possible not only to find considerable commonalities between them, but also to build methodological connections, which enables us to exploit the potential of their articulation.

Given their ability to cross disciplinary divides and to foster social interaction, CLIL and TBLT have been gathering momentum in many education systems across Europe over these past two decades. In fact, an increasing number of schools have been seeking to depart from traditional approaches to language learning, where foreign and second languages are taught as discrete subjects, mostly relying on the activities presented in the textbooks and without any links to other areas of learning. These changes in language teaching have been analysed by a number of authors (for CLIL, see: Lopes, 2018; European Commission/EACEA/Eurydice, 2017; Pérez-Cañado, 2011; Coyle, Hood \& Marsh, 2010; Lorenzo et al., 2009; Dalton-Puffer \& Nikula, 2006; Coonan, 2005; for TBLT, see: Gascoigne \& Parnell, 2013; Andon \& Eckerth, 2009; Adams, 2009; Carless, 2004). However, it should be noted that, if anything, what these studies show is that the implementation of such approaches in the different education systems is far from consensual or consistent.

Taking into account these challenges, this paper seeks to address some of the methodological gaps between CLIL and TBLT, by proposing a framework for designing content-oriented tasks, built on the framework already advanced for the project PETALL (Lopes \& Ruiz Cecilia, 2017). This was a European-funded project that ran from 2013 to 2016 and that aimed at the promotion of TBLT and the creation and implementation of technology-mediated tasks designed in accordance with the guidelines set by the Common European Framework of Reference for Languages (Council of Europe, 2001) (CEFR). Based on this framework a template has been developed to help teachers plan their tasks in a CLIL classroom context. After a theoretical discussion about the ways in which the principles of TBLT and CLIL can be integrated, a template designed to systematise the task will be provided, and examples will be given.

\section{Literature review}

\subsection{The articulation of TBLT and CLIL}

Recently, a number of researchers have been discussing the ways in which CLIL and TBLT can be brought together (Ahmadian \& García-Mayo, 2018; García-Mayo, 2015; Scott \& Beadle, 
2014; Basterrechea \& García-Mayo, 2013). Nevertheless, Ortega (2015) cautiously points out that there are differences in focus that have to be taken into account. The author argues that each approach conceptualizes "meaning" differently (in TBLT it is related to experiential and goal-oriented learning, while in CLIL it is associated with content and subject matter learning), and usually tends to target different age-groups (TBLT has been mostly implemented with college-level language learners, whereas CLIL is mostly applied to school age children). Furthermore, each has its own educational focus. CLIL has been thriving in foreign language contexts where teachers seek to create an input-rich environment in the classroom, while teachers and learners in TBLT are working towards future needs and goals outside the school context. Finally, these approaches serve distinct aims in terms of educational effectiveness. In fact, in TBLT a transfer of learning from the tasks carried out in the classroom to the authentic tasks in the real-world contexts is expected to occur. In CLIL, on the other hand, gains in Ianguage learning and in content learning are supposed to be balanced and mutually beneficial.

These divergences render both approaches neither incompatible nor mutually exclusive. Quite the opposite: it is not just the fact that some of the practical issues raised by the implementation of CLIL can be managed by thoughtful planning of tasks; it is above all the fact that, in methodological terms, TBLT provides the scaffolding needed for CLIL classes to strike a balance between the cognitive and linguistic demands. A report published by the European Commission (Scott \& Beadle, 2014) had already highlighted the need for this articulation by advocating Meyer's (2010) principles for successful and sustainable CLIL teaching and learning. One of those principles, "rich interaction and pushed output", can best be upheld if TBLT is to be made an integral part of CLIL teaching, as it brings authentic communication into the classroom, facilitates the use of the target language in interaction and pushes learners to make use of their resources (Scott \& Beadle, 2014: 16). Meyer further maintains that the relationship between CLIL and TBLT is in fact a symbiotic one, as "authentic and meaningful content is used to create motivating and challenging tasks". Besides, "authentic communication in different cooperative formats (like think-pair-share activities) triggered by those tasks and the frequent negotiation of meaning necessary to complete them enables a greater depth and bandwidth of content learning" (Meyer, 2010: 19).

\subsection{How TBLT can address some of the challenges posed by CLIL}

Despite the significant gains that CLIL provides (Goris, Denessen \& Verhoeven, 2017; PérezVidal \& Roquet, 2015; Muñoz, 2015; Martínez Adrián, 2011), several difficulties have been encountered in its implementation. Blasco (2014), for example, shows in her findings that learners aged 9-10 in a CLIL programme and in a mainstream ELF programme improved their fluency and the syntactic complexity of their oral production throughout the study over a two-year period. This, however, came at a cost, as there was gradual decrease of accuracy. Her findings corroborate Skehan \& Foster's (2001) Trade-off Hypothesis, according to which "great- 
er fluency will be accompanied by greater accuracy or complexity (but not both) due to the fact that attentional resources are limited and, thus, high levels of complexity, accuracy and fluency are unlikely to take place simultaneously" (Blasco, 2014: 339; see also Skehan, 2009). Another challenge in the implementation of CLIL has been the discrepancy between the level required to carry out the work for content learning and the students' actual level (Tardieu \& Dolitsky, 2012). In the same study, the authors also point out that one of the paradoxes of CLIL teaching is the fact that there is usually a separation between the role of content teachers and that of language teachers, who are usually assigned just a supporting role to help enhance the students' language competence. Under this scheme, it is up to the content teachers to plan lessons to teach content and, as a result, communication ends up being supplanted by content. Another equally important issue was raised by Lundin \& Persson (2015), who claimed that the students' engagement and confidence-which help them forget their own insufficiencies - can only be guaranteed if the classroom setting is secure and supportive, and they learn to take risks in oral interaction.

\subsection{Focus of TBLT on social interaction}

To tackle the latter challenges, one of the solutions could lie in resorting to TBLT, with its focus on language as action, encouraging the learner to act as a social actor engaged in real-lifelike activities, rather than just someone trying to assimilate content inside the classroom using L2. In CLIL, nevertheless, the task being proposed to the students has to be appropriate to their level and their ability to internalise conceptual knowledge (Meyer, Halbach \& Coyle, 2015). Another important advantage that TBLT offers to help overcome the students' difficulty in coping with the process of learning content in a second language is its focus on social interaction. Competition (and its correlate concepts, such as competitiveness and competitors (Listra, 2015)) has been one of the values at the core of many contemporary western societies and consequently has conditioned the individuals' attitudes not only towards the labour market, but also towards the school. This has helped foster competitive and individualistic aims set for individual achievement, diverting students from what Gillies \& Cunnington (2014) call "cooperative goal structures". A number of studies dating back to the 1970s had already demonstrated that there were social and academic benefits when children worked together (Brown, Fenrick \& Klemme, 1971; Gartner, Kholer \& Riessman, 1971). In the meantime, several meta-analyses (Johnson et al., 1981; Johnson \& Johnson, 2002) have shown that higher achievement and greater productivity_regardless of the subject areas, age groups or tasks_rested not on individualistic approaches to learning, but rather on cooperative ones. According to Johnson \& Johnson (2009), the reasons for the success in cooperative learning lie in five key components that are expected to be embedded in the structure of the group, namely:

1) establishment of a state of positive goal interdependence, which enables students to realize that, in order to complete their part of the task, they need to make sure that the 
other group members do the same;

2) realization that, although they are part of a group, each one is individually accountable for their contribution;

3) mastering interpersonal and small-group skills, such as listening to others, sharing ideas and resources, taking turns, assuming responsibilities, participating in the democratic decision-making process;

4) promotive interaction, resulting from the deployment of the above skills in reciprocal exchanges, allowing group members to feel valued and willing to help others in return;

5) group processing, which allows members to achieve their goals as a group and to involve themselves in effective working relationships, and which occurs when the group's ideas are summarised, their member are encouraged to participate in group discussions and the group's decisions are backed by all its members. (Adapted from Johnson \& Johnson, 2009).

The ideas underlying these components discussed by Johnson \& Johnson (2009) are rooted in Vygotsky's social constructivist theory and his key concepts of "social interaction", "the more knowledgeable other" and "the zone of proximal development" (Moll, 2014). They also appear to echo Jürgen Habermas's discursive ethics (1998), whose edifice is grounded on two principles. The first one is the principle of discourse ("only those norms can claim validity that could meet with the acceptance of all concerned in practical discourse"). The second is the principle of universalization ("a norm is valid when the foreseeable consequences and side effects of its general observance for the interests and value-orientations of each individual could be jointly accepted by all concerned without coercion"). Although there is a broad range of types of tasks, the pedagogical relevance of most of them relies on how this social dimension-along with the ethical rules underlying the communicative process-plays out in the language classroom.

\subsection{Balancing language and content}

This focus on social interaction notwithstanding, little is achieved if content and language are not effectively integrated and well balanced in terms of workload. Echoing the positions of Mehisto, Marsh \& Frigols (2008) concerning the core feature of multiple focus in CLIL, Ball, Kelly and Clegg (2016) suggest that such integration is successful only if there is reciprocity between both, that is, if language learning is supported in content classes and content learning is supported in language classes. However, the authors also propose that, instead of making it only about learning, it should also be about raising awareness. Therefore, what is also at stake is language awareness occurring in content classes, while promoting content awareness in the language classes. Several research studies have been conducted with the purpose of understanding how this balance can be achieved (Ó Ceallaigh et al., 2017; Cenoz, 
Genesee \& Gorter, 2014; Cammarata \& Tedick, 2012; Fledderus, Knoppert \& Soesbergen, 2011). However, as Cenoz et al. (2014) point out, there is little evidence that pedagogic integration of content and language is more balanced in CLIL than in immersion. As demonstrated by Dalton-Puffer et al. (2009) and Evnitskaya and Morton (2011), most of the times, the problem lies in the fact that content teachers lack formal qualifications in foreign language or language pedagogy, CLIL classrooms do not differ from other classroom where subjects are taught in the first language, and collaboration between language teachers and content teachers is usually scant. These issues can be addressed provided that: a) specific training in language teaching in the context of CLIL is offered to content teachers; b) there is a differentiation between the CLIL classroom and the LI content classroom; c) collaboration between content and language teachers is fostered.

In this latter respect, TBLT can function as a common methodological platform for both content and language teachers to jointly develop their pedagogical projects.

\section{Methodological approximations}

The main characteristics of both CLIL and TBLT are in many respects similar, if not identical. The CLIL goal statements, as laid out in the CLIL Compendium (Marsh et al., 2001) and later discussed by Richards and Rodgers (2014), include such notions as the development of oral and intercultural communication skills, the increase of the learner's motivation, the diversification of methods and forms of classroom practice and the study of content through different perspectives. Later, Mehisto et al. (2008), elaborating on these ideas, proposed what they believed to be the "core features" CLIL:

a) Multiple focus: language and content classes should be properly articulated, supporting language learning in content classes and vice versa, with an emphasis on the reflection on the learning process; several subjects should be integrated and learning should be organised through cross curricular themes and projects.

b) Safe and enriching learning environment: teachers should seek to increase the student language awareness and to build their confidence by letting them experiment with language and content, either through routine activities and discourse, or through guided access to authentic materials and learning environments.

c) Authenticity: the above use of authentic materials, in particular current materials from the media, the exchanges with other speakers of the CLIL language, as well as the accommodation of the student interests, are all aspects that should help to make a "regular connection between learning and the students' lives".

d) Active learning: while teachers should act as facilitators and negotiate the meaning of language and content with students, students should be assigned a pivotal role in CLIL 
lessons, not only by communicating more than the teacher, but also by helping set content, language and learning skills outcomes, evaluating progress in achieving the learning outcomes, and engaging in peer cooperative work.

e) Scaffolding: rather than imposing new knowledge, the teacher should be sensitive to different learning styles and build on the students" "existing knowledge, skills, attitudes, interests and experience", while encouraging them to make use of their creative and critical thinking and to meet the challenges ahead.

f) Cooperation: one of the conditions for the articulation between content and language classes is the cooperative work to be carried out by both CLIL and non-CLIL teachers in planning the courses, lessons or themes; furthermore, parents and the local community should be involved in supporting the students in their CLIL activities. (Adapted from Mehisto et al., 2008).

Most of these ideas are intrinsic to TBLT. Planning cross-curricular projects; building the learner's confidence by experimenting with language and content; encouraging access to authentic materials and environments; meeting their interests and experiences, and making them aware of the connection between what they are learning and the real-life world; shifting the focus of the communicative process from the teacher to the interaction between students; fostering creative and critical thinking - all of these features are equally at the core of TBLT. There is a striking similarity between the above features and the criteria set for the designing of technology mediated tasks, as proposed by Lopes and Ruiz-Cecilia (2017) and Ruiz-Cecilia (2017).

\section{Designing tasks for CLIL}

Besides the methodological commonalities, similarities can also be found in the several stages for the designing and implementation of CLIL and TBLT activities. Coyle (1999), building on the materials used by trainee teacher on the BILD PGCE programme, University of Nottingham, provides the CLIL teachers with a possible blueprint of the planning process, which is divided into five stages.

In stage one, one should first take into account the guiding principles, that is, defining the CLIL context, checking the aims and objectives of the teaching programme, setting the principles for learning and discussing them with the other colleagues.

Stage two concerns the analysis of the teaching curriculum, by auditing the curriculum subject, namely by identifying the content knowledge, skills and understanding that teachers are expected to teach. It also entails relating content to thinking skills or cognitive processing, while considering which linguistic elements are necessary to do this. Coyle (1999) further proposes that a schema or wall chart should be drawn to show the interrelationship and interconnectedness of content, thinking skills and linguistic elements. 
The next stage (three), preparing the learning environment, is where the actual detailed planning is taking place. Schemata are to be used in the definition of the tasks, and appropriate teaching and learning strategies are to be identified, that is, not just the teacher supporting learners, but also helping learners to support their own learning process. Coyle (1999) also suggests the use of the Cummins' (1984) matrix to plot different elements such as CLIL four Cs (content, cognition, curriculum and culture) or thinking skills, language and culture awareness and progression. Besides the preparation of appropriate materials (materials that suit learning strategies and incorporate pedagogical scaffolding), the teachers must set clear and achievable objectives and make sure that tasks abide by a progression-oriented sequence. This progression could be translated into statements such as "by the end of the term, I want my learners to..."-which is the teacher's version of the learner's "I can do..." statement, as defined by the CEFR (Council of Europe, 2001).

Stage four centres on monitoring for progression, which involves collaboration with other teachers to allow data to be collected (via recording, transcriptions or class observations), analysed and evaluated according to negotiated criteria. Collaboration with learners should also be encouraged, for example by clarifying the learning aims, exploring the learners' oral and written production. Assessment should be directed at the process rather than the outcomes.

Finally, in stage five, evaluation for effectiveness, is where the evaluation of the teaching and learning process takes place and of how this relates to the original schema. Again, learners are to be involved to understand how far learning aims were achieved. Based on this evaluation, the schema is to be revised or adjusted and new targets are to be set.

These five stages run parallel (though with some overlaps) to Lopes \& Ruiz-Cecilia's (2017) stages proposed for the designing of technology-mediated tasks.

In the first stage, preparation, teachers not only lay the groundwork for the task, but also make sure that it suits the learning objectives and content of the programme and of the curriculum. The preparation entails the identification and understanding of the learners' needs and interests. This could be based on needs analysis, empirical evidence from classroom observations, or talks with the learners to know more about their demands and expectations. Besides, given the practical use of the language that the task implies, the "can do" focus proposed by the CEFR should be considered. Teachers at this stage should also anticipate the actual conditions for the implementation of the task, including the availability of materials, resources and facilities. This first stage roughly corresponds to Coyle's (1999) stages one, two and three.

Planning, the second stage proposed by Lopes \& Ruiz-Cecilia (2017), is to be done considering the demands, opportunities and constraints identified in the first stage. This requires the setting of objectives, the definition of contents, resources and products, the laying out of the time plan or of different phases of the process and the design of the evaluation tools. 
Teachers must also seek to foresee practical difficulties and problems that may arise during the implementation, either to skirt them or to have solutions ready at hand. Besides the main task, warm-up and consolidating activities should be thought out to enhance the pedagogical effectiveness of the task. This stage matches Coyle's (1999) stage three.

Implementation is the most challenging moment. This means that the success of the project, the predictability of the plan or the certainty of the course of action must rest on working with, and not against, the learners. However, the success also hinges on the teachers' experience and confidence, since they have to be able to monitor several groups at the same time and provide pedagogical assistance to overcome the difficulties and the possible resistance on the part of learners to some aspects of the task.

This third stage, along with the fourth one, evaluation, corresponds to Coyle's (1999) stage four. By giving learners the opportunity to feedback on the activity based on the criteria explained above, teachers can learn more about the learners' progress and the degree of satisfaction. This will also allow teachers to gauge the effectiveness of the teaching and learning process, the achievement of the objectives identified in the course of the preparation phase and the adequacy to the language level. Evaluation can take different forms and several tools can be deployed (questionnaire, interview, direct observation, recording, etc.).

The data collected during the evaluation process (the learners' appraisal of the task, the quality of the outcomes and products, and the teachers' perceptions) is to undergo careful analysis. This constitutes the fifth stage. The analysis and interpretation of the results will enable teachers to identify the vulnerabilities and weaknesses to be addressed, as well as the strengths that need to be fine-tuned or leveraged.

This leads us to the final stage proposed by Lopes \& Ruiz-Cecilia (2017), recasting and refining, which finalises the quality assurance process. Looking at the results, teachers will know if the task fulfilled the objectives, meet the learners' needs and/or expectations and developed their skills and knowledge. Recasting and refining must be based on a reflective process, if possible with the input of learners and other teachers. These last two stages are attuned to the ideas underlying Coyle's (1999) stage five.

\section{Proposing a template}

Based on the above theoretical framework, a template adapted from Lopes \& Ruiz-Cecilia (2017) is proposed below. The original template was meant to be used as a roadmap to help the members of the PETALL project to create their own ICT-based tasks. Given the growing role that technology plays not only in education, but also in the lives of the learners and in the ways in which they think, communicate and express their creativity (Hoffmann, Ivcevic \& Brackett, 2016; Rubin, 2012), this schema retains the technological dimension that was 
originally proposed. An abridged version of the template is available online from the project website (http://petallproject.eu) or can be directly accessed in Google Forms (https://goo.gl/ forms/EJNQ1nXSqcrX5ufz1).

\section{Overview}

\subsection{Linguistic dimension}

1.1.1. CEFR Level: Tasks may target one or several CEFR levels, in which case the teacher needs to make the necessary adjustments.

1.1.2. Skill(s): Tasks may seek to develop all macro-skills (Writing; Reading; Speaking; Listening), but may focus instead on production, comprehension, or specific micro-skills. The CEFR speaks of communicative language activities (Reception, Interaction, Production and Mediation), which reconceptualises the traditional division of skills (see section 4.4 of the CEFR). These activities include oral production (speaking), written production (writing), aural reception (listening), visual reception (reading), audio-visual reception, oral interaction, written interaction and mediating. Further details about the communicative language activities the learner can be engaged in are provided in sections 4.4.1 to 4.4.4 of the CEFR.

1.1.3. "I can do" statements: In order to make sure that the tasks proposed were in tune with the CEFR, the descriptors in table 2, section 3.4, were used. These descriptors helped lend greater methodological coherence to the whole set of tasks.

\subsection{ICT dimension}

1.2.1. ICT resources: The teachers ought to have some command of the resources required (e.g. online dictionaries and grammars, software, websites, apps, etc.) to implement the task. 1.2.3. ICT skills: The PETALL project sought to strike a balance between language-in-use and technology. ICT-related skills the learners are expected to develop or consolidate are no less important than language skills (Griaznova, 2016).

\subsection{CLIL dimension}

1.3.1. Content area: for example: Sciences; History; Geography; Literature.

1.3.2. Topic(s) or question(s) addressed (knowledge): for example: Photosynthesis; European Imperialism in Africa; Rural Exodus; Renaissance Drama.

1.3.3. Content skills to be developed, which depend on the content subject chosen.

1.3.4. Materials: teachers are to provide the reference(s) to the material(s) to be used (including texts, videos, pictures, websites, audio files, etc.).

1.3.5. Processing information from the materials provided: Teachers are to clarify how learners are going to process information related to the content area (analysis of content, identification of linguistic or diagrammatical markers, analysis of illustrations, etc.) (based on Darn, 2006). 
1.3.6. Identification and Organisation of Knowledge: Teachers are to describe how learners are going to categorise ideas and information from the materials provided (namely through diagrams such as tree diagrams for classification, groups, hierarchies, flow diagrams and timelines for sequenced thinking such as instructions and historical information, tabular diagrams describing people and places, and combinations of these) (based on Darn, 2006).

1.3.7. Language identification: Teachers are to explain how useful language in the text is going to be highlighted (for example, subject specific and academic vocabulary, certain discourse markers, adverb phrases or prepositional phrases, collocations, semi-fixed expressions and set phrases). They are also to elucidate how that language can be categorised according to function (for example, comparison and contrast, location or describing a process).

\section{Detailed description of the task}

2.1. Situation/theme(s): Situations and themes can vary greatly, but in general the official syllabi seek to cover the most relevant ones (for example, the topic "professions" can range from job interviews, résumé writing and entrepreneurship to the development of hard and soft skills, etc.).

2.2. Duration: number of minutes and/or number of sessions to help teachers schedule the activities throughout the term.

2.3. Product: In some tasks, the learners are expected to come up with a product or output. Products can be motivating, as they give learners a sense of achievement (Loftus, Tiernan \& Cherian, 2014; Palmgren-Neuvonen \& Korkeamäki, 2014). This can cover a wide range of possibilities. It can go from mere websites (social media, blogs, portfolios), online books (interactive books, comics, illustrated books), videos (documentaries, TV shows, short films) and audio recordings (radio shows, interviews, audio slideshows, audio books, songs), to something more complex and sophisticated as games (created in online tools such as: Kahoot, Buildbox, Gamefront, Sporcle) and animated motion pictures.

2.4. Process: The sequence of steps and/or the work plan are to be detailed here. The methodical planning of the task cycle (which can follow the model proposed by Willis (1996)), including an explanation of its different stages, provides teachers with the sequential framework of actions to be undertaken.

2.5. Division of roles (optional): Division of roles (if any) can bring learners closer to real-life situations. Besides, knowing what is expected from the different actors (either in social or functional terms) should facilitate communication and coordination.

2.6. Consolidating activities suggested or follow-up plan: Reinforcers (activities aimed at memorizing vocabulary, improving pronunciation or consolidating grammar, for example) play a pivotal role in guaranteeing that the activities are translated into effective learning. With such consolidating activities, the whole learning process comes to a full circle.

2.7. Success factors and/or evaluation criteria: Success factors (including the learning style, the learner's assumption of responsibility, the learning environment, etc. (Alberth, 2011; Ali \& 
Elfessi, 2004)) depend on the nature and objectives of the task. In some cases, an assessment grid may be advisable.

\section{Didactic added value of the task and other information}

3.1. Practical hints for teachers: Teachers who have already implemented the task are in a better situation to anticipate problems and provide practical advice on, for example, equipment or the learners' reactions and attitudes.

3.2. Additional methodological or didactic comments: The task needs to be justified in methodological terms. A more theoretical view of the model can always be complemented with more practical understanding of the process.

3.3. Reasons why this task is a model of best practices: The proponents are to reflect on the quality and relevance of the task, and the benefits that the learners and teachers may derive from it.

3.4. Impact that it is expected to have on the teaching practices and attitudes: The task is expected to help teachers find in this type of approach the motivation for pedagogical innovation and quality enhancement.

3.5. Rationale and/or theoretical underpinnings of the task: The rationale must mirror the teachers' methodological positions and core concepts.

\section{Conclusions}

This template seeks to cover a whole range of aspects involved in the designing of a CLIL task. It is intended to be neither prescriptive nor exhaustive. The template is meant, above all, to serve as the starting point for a more thorough reflection on how to operationalise TBLT in the context of the CLIL classroom. The methodological intersections between CLIL and TBLT may be all too apparent, especially given their communicative matrix, but one must always bear in mind that these are distinct approaches. TBLT has been used in the language classroom without the involvement of content teachers, and content teachers are not expected to rely entirely on task in the activities that they carry out in the CLIL classroom.

What one must bear in mind, however, is that there is a growing number of schools that is adopting CLIL, as well as a growing number of language teachers that is now resorting to TBLT (Lopes, 2018). These two phenomena combined increase the chances of the pedagogical concerns of both the language teacher and the content teacher overlapping. The way forward is not pedagogical isolationism, but rather the promotion of collaboration between teachers coming from several areas of knowledge. The effects of bringing TBLT and CLIL together, when properly articulated, can result in the whole being greater than the sum of its parts. In other words, the combination of knowledge, strategies, skills and attitudes that learners acquire in fulfilling the goals of a CLIL task not only increases their ability to act in the world, but also leads to a greater social empowerment, which is, after all, one of the main goals of education. 


\section{References}

AdAms, Rebecca, 2009: "Recent publications on task-based language teaching: A review", International Journal of Applied Linguistics 19 (3), 339-355.

Ahmadian, Mohammad Javad, 2016: "Task-based language teaching and learning", The Language Learning Journal 44 (4), 377-380.

Ahmadian, Mohammad Javad, and María del Pilar Garcia Mayo (eds.), 2018: Recent Perspectives on Task-Based Language Learning and Teaching, Berlin: de Gruyter Mouton.

AlBeRTH, Alberth, 2011: "Critical success factors in online language learning”, TEFLIN Journal $22(1), 16-33$.

All, Ahmed, and Abdulaziz ElfEsSI, 2004: "Examining Students Performance and Attitudes Towards the Use of Information Technology in a Virtual and Conventional Setting", The Journal of Interactive Online Learning 2 (3) [retrieved from http://goo.gl/RCXqcl].

Andon, Nich, and Johannes ECKERTH, 2009: "Chacun à son gout? Task-based L2 pedagogy from the teachers' point of view”, International Journal of Applied Linguistics 19 (3), 286-310.

Ball, Phil, Keith Kelly and John ClegG, 2016: Oxford Handbooks for Language Teachers: Putting CLIL into Practice, Oxford: Oxford University Press.

Basterrechea, María, and María del Pilar Garcia Mayo, 2013: "Language-related episodes during collaborative tasks: A comparison of CLIL and EFL learners" in Kim McDonovgh and Alison MACKEY (eds.): Second language interaction in diverse educational contexts, Amsterdam: John Benjamins, 25-43.

Blasco, Anna Bret, 2014: L2 English Young Learners' Oral Production Skills in CLIL and EFL Settings: A Longitudinal Study. Doctoral dissertation, Universitat Autònoma de Barcelona.

Brown, Lou, Nancy Fenrick and Hope Klemme, 1971: "Trainable pupils learn to teach each other", Teaching Exceptional Children 4, 36-49.

Brgate, Martin, 2016: "Sources, developments and directions of task-based language teaching", The Language Learning Journal 44 (4), 381-400.

Cammarata, Laurent, and Diane Tedick, 2012: "Balancing Content and Language in Instruction: The Experience of Immersion Teachers", Modern Language Journal 96 (2), 153-289.

CARLESS, David, 2004: “ISsues in teachers' reinterpretation of a task-based innovation in primary schools", TESOL Quarterly 38, 639-662. 
Cenoz, Jasone, Fred Genesee and Durk Gorter, 2014: "Critical Analysis of CLIL: Taking Stock and Looking Forward”, Applied Linguistics 35 (3), 243-262.

Coonan, Carmel Mary, 2005: "The natural learning of a foreign language. CLIL as a possible partial solution for the primary school”, Scuola e Lingue Moderne 4-5 [retrieved from http:// primaryclil.org/project\%200utcomes/WP2/The\%20natural\%20learning\%200f\%20a\%20foreign\%2olanguage.pdf].

Council of Europe, 2001: Common European framework of reference for languages: Learning, teaching, assessment, Cambridge, UK: Press Syndicate of the University of Cambridge.

CoyLe, Do, 1999: "Supporting students in content and language integrated learning contexts: planning for effective classrooms" in John MAsIH (ed.): Learning through a foreign language: models, methods and outcomes, London: Centre for Information on Language Teaching and Research [retrieved from https://files.eric.ed.gov/fulltext/ED454735.pdf].

Coyle, Do, Philip Hood and David MARSH, 2010: Content and Language Integrated Learning, Cambridge: Cambridge University Press.

Cummins, Jim, 1984: Bilingualism and special education: Issues in assessment and pedagogy, Clevedon, England: Multilingual Matters.

Dalton-Puffer, Christiane, Julia Hüttner, Veronika Schindelegger and Ute Smit, 2009: "Technology geeks speak out: what students think about vocational CLIL", International CLIL Research Journal 1, 18-25.

Dalton-Puffer, Christiane, and Tarja Nikula, 2006: "Introduction", Vienna English Working Papers 15.(3), 4-7.

DARN, Steve, 2006: Content and Language Integrated Learning (CLIL): A European Overview [retrieved from https://eric.ed.gov/?id=ED490775].

European Commission/EACEA/Eurydice, 2017: Key Data on Teaching Languages at School in Europe - 2017 Edition. Eurydice Report, Luxembourg: Publications Office of the European Union.

EvnitskaYa, Natalia, and Tom Morton, 2011: "Knowledge construction, meaning making and interaction in CLIL science classroom communities of practice", Language and Education 25, 109-27.

Fledderus, Wessel, Ron Knoppert and Floor Soesbergen, 2011: Teaching with CLIL: Learning and Language Come Together, Utrecht University Repository [retrieved from https://bit.ly/37HJnзj].

Garcia-Mayo, María del Pilar, 2015: "Editorial: The interface between task-based language teaching and content-based instruction", System 54, 1-3. 
Gartner, Alan, Mary Kholer and Frank Riessman, 1971: Children teach children: Learning by teaching, New York: Harper \& Row.

Gascoigne, Carolyn, and Juliette Parnell, 2013: "Tasks and Focus on Form: Connections in the US and Europe" in Stephanie Dhonau (ed.): MultiTasks, MultiSkills, Multiconnections. 2013 Report of the Central States Conference on the Teaching of Foreign Languages.

Gillies, Robin, and Ross Cunnington, 2014: "Cooperative learning: The behavioural and neurological markers that help to explain its success", paper presented at ACER Research Conference 2014 [retrieved from https://core.ac.uk/download/pdf/30674099.pdf].

Goris, José, Eddie Denessen and Ludo Verhoeven, 2017: “The contribution of CLIL to learners' international orientation and EFL confidence", The Language Learning Journal 47 (2), 246-256.

GrIAZNOVA, Elena, 2016: "The development of ICT-competencies of the students at foreign language lessons as the basis for successful learning and cognitive activity”, Pacific Science Review6 (4), 226-229.

Habermas, Jürgen, 1998: The inclusion of the Other. Studies in Political Theory, Cambridge: MIT Press.

Hanesova, Dana, 2015: "History of CLIL" in Silvia Pokrivčákova et al. (eds): CLIL in Foreign Language Education: e-textbook for foreign language teachers, Nitra: Constantine the Philosopher University, 7-16 [retrieved from https://cutt.ly/wriYsiY].

Hoffmann, Jessica, Zorana Ivcevic and Marc Brackett, 2016: "Creativity in the Age of Technology: Measuring the Digital Creativity of Millennials", Creativity Research Journal 28 (2), 149-153.

Johnson, David, and Frank Johnson, 2009: Joining together: Group theory and group skills, Upper Saddle River, NJ: Pearson Education.

Johnson, David, and Roger Johnson, 2002: "Learning together and alone: Overview and meta-analysis", Asia Pacific Journal of Education 22, 95-105.

Johnson, David, Geoffrey Maruyama, Roger Johnson, Deborah Nelson and Linda Skon, 1981: "Effects of cooperative, competitive, and individualistic goal structures on achievement: A meta-analysis", Psychological Bulletin 89, 47-62.

LISTRA, Enn, 2015: "The concept of competition and the objectives of competitors", Procedia Social and Behavioral Sciences 213, 25-30.

Loftus, Maria, Peter Tiernan and Sebastian Cherian, 2014: "Students' readiness to move from consumers to producers of digital video content: A cross-cultural analysis of Irish and Indian Students", Education \& Information Technologies 19 (3), 569-582. 
LoPEs, António, 2018: "How bold are language teachers? Results of an international survey on technology-mediated task-based language teaching” in António Lopes and Raúl Ruiz-CeCILIA (eds.): New Trends in Language Teaching: methods, evaluation, training, Newcastle upon Tyne: Cambridge Scholars Publishing.

Lopes, António, and Raúl Ruiz-CeCILIA, 2017: “Designing technology-mediated tasks for language teaching: a methodological framework", Hacettepe Üniversitesi Journal of Education $32(2), 265-279$.

Lorenzo, Francisco, Sonia Casal, Pat Moore and Yeray Afonso, 2009: Bilingüismo y educación. Situación de la red de centros bilingües en Andalucía, Sevilla: Fundación Centro de Estudios Andaluces.

Lundin, Charlotte, and Linda Persson, 2015: Advantages and Challenges with CLIL: a study examining teacher's thought on learner engagement and confidence within content and language integrated learning, Malmö Högskola.

Marsh, David, Anne Maljers and Aini-Kristiina HaRTIALA, 2001: Profiling European CLIL Classrooms, UniCOM: University of Jyväskylä.

Martínez Adrián, María, 2011: "An overview of Content and Language Integrated Learning: origins, features and research outcomes", Huarte de San Juan. Filología y Didáctica de la Lengua 11, 93-101.

Mehisto, Peeter, David Marsh and María Jesús Frigols, 2008: Uncovering CLIL, London: Macmillan.

Meyer, Oliver, 2010: "Towards quality-CLIL: successful planning and teaching strategies", Pulse 33, 11-29.

Meyer, Oliver, Ana Halbach and Do Coyle, 2015: A Pluriliteracies Approach to Teaching for Learning: Putting a pluriliteracies approach into practice, European Centre for Modern Languages and Council of Europe [retrieved from https://bit.ly/36zCxwS].

MolL, Luis, 2014: L.S. Vygotsky and Education, New York: Routledge.

Muñoz, Carmen, 2015: "Time and Timing in CLIL: A Comparative Approach to Language Gains" in María Juan-Garau and Joana Salazar-Noguera (eds.): Content-based Language Learning in Multilingual Educational Environments. Educational Linguistics, London: Springer, 87-104.

Ó Ceallaigh, T. J., Siobhán Ni Mhurchú and Déirdre Ni Chróinín, 2017: "Balancing content and language in CLIL: The experiences of teachers and learners", Journal of Immersion and Content-Based Language Education 5 (1), 58-86. 
ORTEGA, Lourdes, 2015: "Researching CLIL and TBLT interfaces”, System 54, 103-109.

Palmgren-Neuvonen, Laura, and Ritta Liisa Korkeamäkı, 2014: "Review article: Group interaction of primary-aged students in the context of a learner-generated digital video production", Learning, Culture and Social Interaction 3 (1), 1-14.

Pérez-Cañado, María Luisa, 2011: "CLIL research in Europe: past, present, and future”, International Journal of Bilingual Education and Bilingualism 15 (3), 315-341.

Pérez-Vidal, Carmen, and Helena Roquet, 2015: "The linguistic impact of a CLIL Science programme: An analysis measuring relative gains”, System 54, 80-90.

Richards, Jack, and Theodore Rodgers, 2014: Approaches and Methods in Language Teaching, Cambridge: Cambridge University Press.

RUBIN, Jim, 2012: "Technology's Impact on the Creative Potential of Youth”, Creativity Research Journal $24(2-3), 252-256$.

RuIz-CECILIA, Raúl, 2017: “Reframing Foreign Language Learning and Teaching: ICT-based Tasks” in Davide CAPPERucci and Elizabeth Guerin (eds.): Innovative European Approaches for In-service and Pre-service English Language Teachers in Primary Education. Theory and Practice, Bologna: Edizioni ETS, 137-165.

SCOTt, David, and Shane BEADLE, 2014: Improving the effectiveness of language learning: CLIL and computer assisted language learning. A report submitted by ICF to European Commission [retrieved from https://bit.ly/2T27SnK].

SkeHAN, Peter, 2009: "Modelling Second Language Performance: Integrating Complexity, Accuracy, Fluency, and Lexis", Applied Linguistics 30 (4), 510-532.

Skehan, Peter, and Pauline Foster, 2001: "Cognition and tasks" in Peter Robinson (ed.): Cognition and second language instruction, Cambridge, UK: Cambridge University Press, 183-205.

TARDIEU, Claire, and Marlene Doltisky, 2012: "Integrating the task-based approach to CLIL teaching" in Juan de Dios Martínez Aaudo (ed.): Teaching and Learning English through Bilingual Education, Newcastle: Cambridge Scholars Publishing, 3-35.

Wilus, Jane, 1996: A Framework for Task-Based Learning, Harlow, UK: Longman Addison Wesley. 